\title{
HARVESTING SMALL TREES AND FOREST RESIDUES
}

\author{
BRYCE J. STOKES
}

USDA Forest Service, Southern Forest Experiment Station, DeVall Drive, Auburn, AL 36849, U.S.A.

\begin{abstract}
Eight countries collaborated and shared technical information on the harvesting of small trees and forest residues in a three year program. Proceedings and reports from workshops and reviews are summarized in a review of activities and harvesting systems of the participating countries. Four databases were developed for harvesting and transportation of these materials.
\end{abstract}

\section{KEYWORDS}

Harvesting; residues; forest biomass; transportation: databases.

\section{INTRODUCTION}

This Activity focused on the harvesting of small trees and the recovery of residues for energy. The objective was: "To develop systems for harvesting small trees and forest residues in conventional forestry including considerations of transport, system evaluation, economics, and environmental implications." Countries participating were Canada, Italy, New Zealand, Norway, Sweden, Switzerland, United Kingdom and the U.S.A.

The goals were: (1) Review methods for estimating amount of biomass, (2) Compile information databases for harvesting system production and cost in respect to equipment type, forest type, biomass levels, and utilization levels for small trees and residues, (3) Compile information databases for transportation system production and costs for small trees and residues, (4) Identify and evaluate new alternatives and concepts, and (5) Review environmental aspects of intensive recovery of woody biomass.

The activity objectives were met by the exchange of scientific and professional information at workshops, meetings, and study tours. An international conference was held in the United States in 1989 in order to establish interest and participation and identify research and operational activities in this area. It was followed by workshops and study tours in Denmark in 1990 and New Zealand/Australia in 1991.

Others methods included the identification, compilation, assessment, and review of past, current, and potential technology, techniques, and practices pertinent to the scope of the activity for publication and dissemination. Information was disseminated through the publication of proceedings and reports. Computer databases were developed that covered harvesting and transportation systems for North America and Scandinavia. The efforts involved in the first and last objectives listed above are not reported in this paper. 
The following is an overview of conditions within each country and summarizes the information contained in the reports and four databases.

\section{DENMARK}

\section{Background}

Most consumption of fuel from forests is by district heating plants which currently supply $60 \%$ of the homes in the country. Energy chip consumption increased from 50,000 $\mathrm{m}^{3}$ (loose volume) in 1982 to $700,000 \mathrm{~m}^{3}$ in 1987 , boosted by government incentives via a heavy tax on fossil fuels. Fuel demand then leveled off and actually decreased during the period 1988-1990 because of mild winters. It is expected to increase as more biomass plants come on line and other plants convert from coal and oil.

\section{$\underline{\text { Harvesting_Svstems }}$}

In order to reduce the costs of biomass fuels, work has concentrated on the use of multi-tree handling and improved chipping methods and technology (Suadicani, 1989). Stems are felled (by chainsaw or feller-buncher), allowed to dry, then processed by mobile chippers. This method is used operationally. Experimental trials are underway with harvesting of energy products from clearcuttings. Here, the trees are felled by feller-buncher, forwarded to roadside, and chipped by a relatively large chipper (Kofman, 1990).

\section{FINLAND}

\section{Background}

Finnish silviculture usually calls for three thinnings before final harvest. There is considerable potential to increase harvesting volumes from early thinnings, where tree size is around 0.025 to $0.05 \mathrm{~m}^{3}$ (Mikkonen, 1989). Finland's use of wood energy has decreased, from $45 \%$ of total energy consumption in 1960 to $10 \%$ in 1985. This still represents a larger fraction than in most developed countries. Most use is by farmers who supply their own energy needs and wood industry firms which utilize mill wastes.

A national energy policy developed in 1983 called for an increase in use of wood fuels to an equivalent of six million $\mathrm{m}^{3}$ by 1995 . Declines in oil prices since that time have limited the use of wood, which also must compete with peat and hydroelectric power (Petajisto, 1988). Industry and farm uses of wood fuel are already at high levels, so any future increases in demand for forest-derived energy are expected to come from district heating plants (Hankala, 1988).

\section{Sarvesting e $\mathrm{m} \mathrm{s}$}

Shortwood systems are used almost exclusively in Finland. Thirty percent of the volume is harvested by motor-manual/farm tractor-based systems. Large contractors account for the remainder. These contractors typically use mechanized systems. Grapple harvesters dominate and are used mainly in final harvests. More are working in second or third thinnings. Mechanized processors and harvesters are still too expensive for use by small producers, i.e. with outputs of less than $5000 \mathrm{~m}^{3}$ per year.

Several companies in Finland, as in Sweden, have installed new drum delimber/debarkers at their pulp mills. These utilize small trees which are expensive to delimb in the stand by single-tree equipment 
such as harvesters and processors. First thirmings are therefore more cost effective and more pulp and residues for energy can be delivered to the mills.

\section{NORWAY}

\section{$\underline{\text { Background }}$}

In Norway, small trees are harvested in early thinnings of conifer stands and removals of smaller broadleave trees. At present, most of these materials are utilized for pulp. The availability of oil and gas from the North Sea and a large supply of hydroelectric power result in relatively low energy prices. Norway, compared to its Scandinavian neighbours, therefore uses relatively little forest biomass for fuel. The majority is used for domestic heating, although the metallurgical industry also consumes one million $\mathrm{m}^{3}$ (Gjolsjo, 1988).

\section{Harvesting Systems}

Tree sizes are small and ownerships are mainly small, so $45 \%$ of the annual harvest is recovered by farm tractors equipped with various forestry attachments. The rest is harvested by specialized Scandinavian forestry equipment such as harvesters and forwarders.

Mechanized thinning has been economically feasible with trees of $10-15$ trees per $\mathrm{m}^{3}$. Thirmings of trees half this size are needed and tests have been conducted with relatively small, inexpensive mechanized equipment and combinations of motor-manual felling, mechanized delimbing, debarking, and chipping (Lisland, 1990). Costs were high but much less than with single-tree processing. The smaller, cheaper mechanized equipment results in improved economics for the early thinnings. Some small tractor-based highlead systems are used for strip/selection thinning on steeper terrain, mostly by farm families.

\section{SWEDEN}

\section{Background}

Sweden has a strong emphasis on the collection of small stems from thinnings and residues for energy. This is driven by the lack of domestic fossil fuel resources and the recent decision to phase out nuclear power. The phaseout is expected to double the cost of electricity to industrial consumers over the next ten to fifteen years (Hultkrantz, 1988). The Swedish forest industry is the largest consumer of electricity, so demand by pulp and paper mills as well as district heating plants make the use of forest residues more attractive than in most other developed countries.

To improve forest health, Sweden currently needs to increase the amount of first thinnings to a level exceeding the recent total thinning area. Countering these trends are restrictions on large areas of forest lands which prevent the removal of the total biomass of the tree to retain nutrients on the site. This has led to recent investigations, still in early stages, of pulp chip harvesters (Froding, 1989).

\section{Harvesting Systems}

Collection of logging residues after clearcutting has been common since the 1970's and has been accomplished by stand-mobile chipping units. The high costs of this method have resulted in the development of bulk or bundle handling of small trees from first thinnings. Strip roads spaced at 30-m intervals dictate the use of feller-bunchers operating from the road and motor-manual felling away from 
the roads. Forwarders equipped with grapple saws extract the material to roadside. Pulpwood and energywood are removed on a first pass, sawlogs on a second. Tree sections are stacked at roadside and allowed to self-compact for about a week. High-sided aluminum panels are used on the haul trucks. The panels weigh 3 tonnes and reduce the net load weight capacity by ten percent. The loader is used to help compact the tree sections into the trucks. The tree sections are processed through drum delimber/debarkers at the pulp mill. The system allows the recovery of more pulpwood, more fuel at lower cost, and improved site conditions in the forest (Kvist, 1988).

The majority of trees in first thinnings are in the $6-10 \mathrm{~cm}$ dbh range, so multi-tree handling is essential. The largest improvements via multi-tree handling have come in tree-section systems (Brunberg and Svenson, 1990). Trees bunched by feller-bunchers are bucked and loaded by forwarders equipped with grapplesaws. While the tree sections are currently delimbed and debarked at final destination for use in manufacturing pulp, the tree section harvesting methods are fully applicable to fuel collection operations. With a small feller-buncher, productivity increased $15 \%$ every time two trees were handled by a feller buncher instead of one, and average increases were on the order of 2-6\%. With larger machines operating from the strip-road, increases of $3040 \%$ might be achieved. When producing delimbed roundwood in denser stands, productivity increases of up to $37 \%$ have been obtained by processing two stems simultaneously with a single-grip harvester.

\section{UNITED KINGDOM}

\section{Background.}

Much of the limited forest resource is located in southern Scotland, far from much of the industrial area. Coal reserves and North Sea oil and gas supplies result in only 900,000 tonnes per year commercial use of forest biomass. Half of this is forest residues and small trees from scrub woodlands, while the remainder is mill residues (Mitchell et al., 1988). Some residues are collected by stand-mobile chippers. This material is utilized for high-valued products such as garden mulch. Thinnings amount to about 1.6 million $\mathrm{m}^{3}$ per year, but are utilized for roundwood.

\section{Harvesting Systems.}

Several trials have been undertaken on systems for recovery of residues and conventional products from thinnings and premature clearfelled stands. Strip thinnings were felled with chainsaws, then chipped with various stand-mobile units, including a self-contained chipper, two trailer-mounted units and a prototype chunker. A whole-tree system utilized a feller-buncher and a tractor-mounted processor at the landing. The in-woods chipping of whole trees was cheaper (stump-to-truck costs) by a factor of three than roadside methods for production of fuelwood chips or chunks (Table 1).

\section{ITALY}

In Italy's alpine forests, the role as a producer of wood has taken lower priority to those of recreation and environmental protection (Pollini et al., 1989). Further south, pine forests are used more extensively for production.

Baldini and Spinelli (1990) reported that stands of pine regenerated after fires require thinning, but $70 \%$ of Italian forests are owned by small owners who have limited capital and operations experience. Recent trials have focused on identifying feasible systems for thinning under these conditions. In all cases whole trees were extracted to roadside. Motor-manual methods were used to fell and bunch. A frame-mounted chainsaw was found more efficient than other equipment. Extraction by mini-skidder 
Table 1. Fuel chip harvesting costs in United Kingdom

\begin{tabular}{|c|c|c|c|c|c|}
\hline & $\begin{array}{l}\text { In stand } \\
\text { Chipping }\end{array}$ & $\begin{array}{c}\text { Thinning } \\
\text { Roadside } \\
\text { ipping }\end{array}$ & Chunking & $\begin{array}{l}\text { Clearfell } \\
\text { Roadside } \\
\text { chioping }\end{array}$ & $\begin{array}{l}\text { Thinning } \\
\text { Integrated } \\
\text { harvesting }\end{array}$ \\
\hline \multicolumn{6}{|l|}{ Motor-manual } \\
\hline felling & 2.30 & 3.40 & 3.40 & 3.00 & \\
\hline Felling and bunching & & & & & 6.50 \\
\hline Whole-tree skidding & & 14.00 & 14.00 & & 7.70 \\
\hline Whole-tree forwarding & & & & 5.60 & \\
\hline Stand-mobile chipping & 8.00 & & & & \\
\hline Roadside chipping & & 13.40 & & 10.40 & 9.70 \\
\hline Roadside chunking & 7.20 & & & & \\
\hline Total & 10.30 & 30.80 & 24.60 & 19.00 & 23.90 \\
\hline
\end{tabular}

was less costly than the use of a farm tractor or two-stage extraction. Of the processing options tested, whole-tree chipping was preferred.

\section{SWITZERLAND}

As in many developed countries, approximately $20 \%$ of the wood yield from Swiss forests is used for energy, although stated goals propose to increase this amount. At present, the high costs of manual logging of small trees on steep terrain make wood uncompetitive with oil (Table 2). Future research and development will be aimed at small-scale mechanized harvesting and heating plants with low exhaust emmisions (Steinmann, 1990).

Table 2. Costs of producing fuel chips in Switzerland.

$\begin{array}{lc} & \text { US\$/tonne } \\ \text { Logging } & 59 \\ \text { Chipping } & 27 \\ \text { Storage/drying } & 20 \\ \text { Transportation } & \underline{17} \\ \text { Total } & 123\end{array}$

NEW ZEALAND

\section{Background}

Wood energy consumption in New Zealand takes two forms, household fuelwood and mill residue use by the forest industry. Although New Zealand is heavily dependent on imported oil, domestic natural gas is currently used for both industrial and home heating. Wood provides about $4 \%$ percent of New Zealand's energy needs. No small trees or harvesting residues are used for industrial energy or largescale heating. Potential residues are estimated at 60 to 70 oven dry tonnes (odt) per hectare on clearfelled sites after removal of conventional products (Twaddle, 1987). 
Thinnings of radiata pine during the early 1990's will contribute a lower fraction of total harvest than in the past. Cable thinnings on steep terrain have been discontinued because of high costs and damage to residual trees. One major company has eliminated early thinnings altogether. Thinnings have three major problems including low product values, need to protect the final crop trees, and the need to accumulate satisfactory loads for transport to roadside. Currently, motor-manual felling is used in over 90\% of thinnings (McConchie and Terlesk, 1990).

\section{Harvesting Svstems}

Motor-manual methods dominate in New Zealand, the most common being chainsaw felling followed by tree length extraction by wheeled skidder. Processing is done by chainsaw at the landing. The large size of clear-felled trees precludes the use of more mechanized systems, although some are being used in thinnings (Raymond, 1989). Recent tests have shown feller-directors and feller-bunchers to have excellent potential to reduce costs.

Trials with several systems (skyline yarder, cable skidder, delimber/feller/buncher, tricycle prebuncher) have shown that stand reorganization, e.g. planting small groups at final crop spacing or using paired rows of thinnings and final crop trees, significantly reduces damage to residual trees and increases harvesting productivity.

Research work with organized felling, which increases load size, has indicated the technique can increase extraction productivity and reduce total stump-to-landing costs, especially on flatter terrain. To date, the method has only been partially accepted into practice. Double-drum winches mounted on skidders are becoming more common as a means to accumulate loads in small thinnings. Small portable or self-propelled winches have been tested for prebunching on steep terrain. They may hold some promise for tractor logging on steep ground. Tricycle undercarriage prebunchem have been used to accumulate small trees for grapple skidders. Although effective, the use of the machines for prebunching has decreased recently because of the increase in thinning piece size, mechanical problems when operated in the stand, and operator discomfort.

A system for harvesting fuel chips was introduced in 1988. Trees "were felled with chainsaws and chipped by a stand-mobile forwarder-mounted -chipper. The system was abandoned after several months, due in large part to the low prices of competing fuels.

\section{CANADA}

\section{Background}

Canada has a significant potential for the production of biomass fuels, with 65 to 70 million $\mathrm{m}^{3}$ of small trees and residues available on sites harvested for commercial products (Pottie, 1987). Western Canada has the largest surplus, both from sort yard debriis and logging residues. Even with the high availability, and the fact that the forest industry consumes $80 \%$ of total industrial energy in British Columbia, little of the material is utilized. This is due to the low costs of oil and natural gas, and the lack of an arrangement to compensate producers for power produced via co- generation (Manning, 1987).

Eastern Canadian sources of forest biomass fuel include slash at roadside, residues, residual trees on harvested units, unmerchantable trees and/or stands, and thinnings (Guimier, 1989). The energy situation is similar to that of Western Canada; low prices of alternative fuels and high harvesting and transportation costs restrict the use of forest biomass for energy. Competing uses may also reduce the potential supply of residues for fuel. These include composite wood product plants which manufacture medium-density fiberboard, oriented-strand board, and particleboard. Companies are also considering using forest residues for subgrade material for roads on wet sites. 
Recently-installed heating plants which utilize fuel chips have supported some harvesting activity on. Prince Edward Island (McKnight, 1988). Some provinces are requiring regeneration of slash-covered areas at roadside, which may constitute up to $4 \%$ of total harvested area. When close to mills, these residues are candidates for use as fuel.

\section{Harvesting_Systems}

In Western Canada, trees are processed into delimbed tree-lengths or log-lengths in the stand, so most residues are left scattered on the cutover and are too expensive to recover. The merchantable material is commonly transported to central sort yards for further processing and distribution. Large quantities of residues accumulate at these sort yards, but are not utilized. Long hauling distances pose a major economic problem impeding utilization.

Smaller trees and flatter terrain dictate different harvesting methods in Eastern Canada than in the West. Average tree size at harvest in Eastern Canada rarely exceeds $0.20 \mathrm{~m}^{3}$. Whole tree logging by feller buncher and skidder with delimbing at roadside remains the most popular system (Table 3). The most efficient felling machines for Eastern Canadian conditions are high-speed circular saw heads. Grapple skidders are the most productive at short distances. Cable skidders pulling several bunches with long chokers are highly efficient and commonly used at longer distances (Gingras, 1989). Interest in mechanized tree-length and cut-to-length systems are increasing (Gingras 1990). This is due to the desire to eliminate slash piles at roadside, to recycle nutrients, and to reduce soil disturbance. Recent trials have evaluated disc and drum chippers for comminuting piled residues.

Table 3. Wood harvesting systems in Eastern Canada in 1989.

$\begin{array}{lc}\text { Feller-buncher/wheeled skidder } & 57 \\ \text { Motor-manual felling (fułl tree) } & 16 \\ \text { Motor-manual felling (tree length) } & 15 \\ \text { Feller-forwarder } & 6 \\ \text { Motor-manual felling (shorhvood) } & 4 \\ \text { Cut-to-length harvester } & 2\end{array}$

A few commercial operations are utilizing trees from unmerchantable and dead stands. In most cases, chippers located at roadside are currently preferred over stand-mobile chipping. Small trees are mechanically felled, bunched and skidded or forwarded to landings. Trials of a French stand-mobile brush harvester which harvests, cornminutes and transports, are planned for various locations in eastern Canada.

\section{UNITED STATES}

\section{Background.}

Total consumption of wood for fuel amounts to 150 million $\mathrm{m}^{3}$ per year. The Pacific Northwest has large supplies of underutilized woody biomass. Residues on clearfelling units often exceed 220 tonnes per hectare. Other stands consist of stagnant, heavily overstocked small trees. Conventional harvesting of these stands has not been profitable due to the small piece size.

Although mill wastes are utilized by the forest industry, abundant hydroelectric power has eliminated any incentive to generate power for users outside the forest products industry (Lambert, 1989). As in 
other parts of the world, many of the efforts to utilize small trees began as whole-tree chipping and have now evolved into approaches for producing clean pulp chips (Edman, 1989).

California has a very strong market for forest biomass because of artificially high prices resulting from a political decision in the early 1980s to promote alternative producers of electric power. Approximately three million odt of forest-derived fuel was used in 1988. Most came from thinnings or preharvest of small trees. Forest residues are still too expensive to collect, partly due to difficult terrain (Hartsough, 1989).

Forests in the Intermountain region are also predominantly on steep terrain, resulting in high costs for recovery. An oversupply of mill residues and lack of strong markets for wood fuel limit the recovery of residues (Johnson, 1989). Small tree harvesting and residue recovery in the Lake States is' usually performed as part of a land management prescription and would not otherwise be economic. Trees are used for pulpwood, residential firewood, and fuel chips. In the South, fuel prices are relatively low at present, but whole tree chipping continues because of the site preparation benefits that accrue from the removal of the non-merchantable biomass. One study by McMinn and Clark (1989) found that wholetree harvesting in the South removed approximately 60 percent more residue than would be recoverable in post-harvest operations (Table 4).

Table 4.Estimated recovery amounts after conventional harvesting and with whole-tree harvesting.

\begin{tabular}{|c|c|c|}
\hline Total on site & $\begin{array}{l}\text { Recoverable after } \\
\text { Conventional Harvest }\end{array}$ & $\begin{array}{l}\text { Recovered with } \\
\text { Whole Tree Harvest }\end{array}$ \\
\hline \multicolumn{3}{|c|}{ 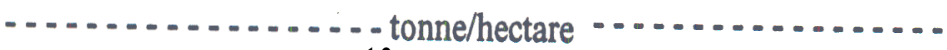 } \\
\hline 20 & 12 & 18 \\
\hline 30 & 17 & 27 \\
\hline 40 & 23 & 36 \\
\hline 50 & 29 & 46 \\
\hline 60 & 35 & 55 \\
\hline 70 & 41 & 64 \\
\hline 80 & 46 & 73 \\
\hline 90 & 52 & 82 \\
\hline 100 & 58 & 91 \\
\hline 110 & 64 & 100 \\
\hline
\end{tabular}

\section{$\underline{\mathrm{H} \text { a rv }}$ e s t i n g}

A wide range of harvesting systems operate'in the USA because of the diversity of conditions. Most systems for conventional products are based on extraction of tree-length, long-length or log-length extraction to roadside. Some whole tree systems are in operation, as are shortwood systems in the Lake States and Northeast. Even within a single subregion, such as the Southeast, simulation models have shown large cost differences due to slope, stand size, and other site differences (Young et al., 1989).

Mechanized systems using harvesters are becoming more popular for thinning in the Lake States. Chipping for fuel is being done at roadside in pine thinnings and clearfelling for stand conversions (Sturos and Thompson, 1989).

Residue collection for biomass is rare with most of the activity being in California. Tests with chipping stockpiled forest residues at roadside with conventional chippers have found production rates to be half of those with whole trees (Johnson, 1989). A number of stand-mobile residue chip harvesters were designed to recover residues, but none persisted past the development stage. Balers have been developed to compact low-density residues, but none have been commercially successful to date. 
Comminution of small trees and residues into chunkwood has been tested but has not moved into commercial use.

Many in-woods fuel recovery systems are in operation in the Southeast and in California Most utilize feller-bunchers (generally rubber-tyred), grapple skidders and large chippers operating at the landing. When site preparation benefits are taken into account, harvesting of energywood has been economically feasible in some cases (Watson and Stokes, 1989; Brinker and Tufts, 1989). A few stand-mobile chippers have been developed (Stokes and Sirois, 1989).

Although flail delimbing and debarking dates back many decades, recent years have seen major increases in the their use at the landing (Stephenson, 1989). In some cases the residues are carried back into the unit by the skidders on the travel-empty leg of the skidding cycle. Some efforts are being made to utilize the residues for energy. A tub grinder, operating simultaneously with the delimber/debarker, has successfully cornminuted residues in Southeastern Oklahoma (Baughman et al., 1990). Green weight of fuel amounted to one-fourth to one-third of the total clean chip plus fuel weight. Various modifications to tub grinders have been tested in attempts to fully load conventional chip vans. In the future, one company plans to recover all residues from flails by using tub grinders. Other companies have not yet followed this lead. Low fuel prices in most areas of the United States do not justify chipping whole trees for fuel.

At least one firm has been successful in moving whole trees to their pulp mill. Specially-designed trailers transport the stems to the mill yard, where the whole trees are delimbed and debarked in a long drum (Twaddle et al., 1989).

\section{HARVESTING SYSTEMS DATABASES}

\section{North America}

A literature review identified equipment and systems which have been tested and/or used commercially to harvest small trees and forest residues in North America (Hartsough and Stokes, 1990a). A database, including 160 partial or complete systems, was developed from the literature (Hartsough and Stokes, 1990b). Parameters for each system included site, material and product characteristics, equipment mix, and production rate. Onto truck and delivered costs per green tonne and breakeven oil prices were developed using standard costing methods adjusted to 1990 dollars. Systems costs were compared over the ranges of piece size, volume per unit area removed, capital/labour ratio, and other variables. Feasibilities of various systems were also compared.

The average costs in the various studies decreased as piece size increased. However, there were several instances where costs for small pieces were as low as for larger material. On the average, costs for residues were similar to those for trees. In general, costs decreased as the amount of material removed per unit area increased, however, some low costs were reported for low removal levels.

Costs for harvesting small trees varied widely between studies. The range of costs for clearcutting and thinning was greater than for preharvesting and postharvesting. This is due to the inclusion of a few studies of clearcutting or thinning of extremely small trees.

The average costs for residues at the landing were less than for in-woods residues. A few cases of in woods recovery at less than US\$10/tonne were reported.

The feasibility of small tree and residue systems depends on their competitiveness with alternative fuels. Assuming that oil is the fuel to be replaced, the price of oil must exceed the breakeven price for a system to be feasible. Under the assumptions made for the study, the median breakeven prices for the various categories of small tree and residue systems were: 


\section{Material System/Location. Breakeven Price,USS/BBL.}

Small Trees

$\begin{array}{lll} & \text { Clearcutting } & 30 \\ & \text { Thinning } & 30 \\ & \text { Preharvesting } & 26 \\ \text { Residues } & \text { Postharvesting } & 30 \\ & & \\ & \text { In-woods } & 38 \\ & \text { At landing } & 25\end{array}$

$\underline{\text { Scandinavia }}$

Information from the literature was assembled into a database (Molbak and Kofman, 1991), using a template similar to that for the North American systems. In contrast to the North American systems, most Scandinavian systems operate cold rather than hot. Hot systems usually demand large wood supplies and expensive equipment. In Scandinavia, most energy material is small first thinnings, many from small blocks, so volumes and production rates cannot support hot systems. Cold systems are also preferred because material is usually left in the stand to dry before chipping, and the systems are less sensitive to interruptions.

In Denmark, fuel material is derived from first thinnings and clearcutting of low-quality first rotation pines planted on sandy soils. Motor-manual felling still predominates, but the number of fellerbunchers are increasing. Stand-mobile chippers are used almost exclusively. Forest owners who do their own chipping generally use agricultural tractor-mounted machines. The earlier versions were hand-fed, but crane-fed models have become more popular during the 1980's. The tractors tow hightipping chip reservoirs on trailers. Contractors prefer specialized higher production chipper-forwarders.

The other Nordic countries usually s chip fuel material at roadside due to steeper terrain and snow conditions which restrict in-woods operations during winter. Felling is done by chainsaw and the material is usually transported to the landing on forwarders. Sources of fuel material in Finland include non productive broadleaved stands on abandoned farms, early thinnings and slash from final harvests. In Sweden, fuel is derived from first thinnings and from slash and whole-tree residuals from clearcuts.

\section{TRANSPORTATION DATABASES}

\section{North America}

A database of currently available truck and truck-trailer equipment for transporting small trees and forest residues being used in North America was compiled by the Forest Engineering Research Institute of Canada (1990). The document is organized as a series of fact sheets that present technical information on the transportation methods, products transported, and equipment. Equipment was grouped into 14 categories. Abstracts of literature relating to each of the categories was reported. Of the 14 systems, nine applied to tree-length or log-length roundwood. One, semi-trailers with partially boarded sides, was used for whole trees. The other four systems (tandem trucks with some type of container or pallet, chip vans, B-train vans and off-highway dump trucks) were used to transport chips or unprocessed residues. The large payload capacity of B-trains makes then attractive, where they are legal, for any short-length material or chips.

\section{Scandinavia}

Axelsson and Bjorheden (1991) discussed the selection and appropriateness of equipment for transporting small trees and residues in Scandinavia. They presented examples of currently available 
truck and truck trailer configurations. Technical specifications and costs are given for the selected equipment.

Development and choice of system is affected by many factors. Among the most important are: (1) the characteristics of the transported material, (2) the length and standard of the haul route, and (3) traffic and safety regulations.

Regulations. Weight limits vary from country to country, and even within a single country (Table 5). Because of the relatively low bulk densities of small trees and residues, volume (length and height) restrictions, which also vary, may be more limiting than weight. At longer haul distances, transportation costs are almost directly proportional to payload weight; therefore, achieving large payloads is a critical need. Weight and volume restrictions play major roles in the economic feasibility of the use of forest biomass for energy.

Table 5.Maximum GVW and overall length in Scandinavian countries.

\begin{tabular}{lcc} 
Country & GVW. tonnes & Length.m \\
\cline { 2 - 3 } Denmark & 40 & 18.5 \\
Finland & 56 & 22.0 \\
Norway & 50 & $18.5(22)$ \\
Sweden & 56 & 24.0
\end{tabular}

Material, Forest biomass comes in many forms. In addition, it may be processed at the source, at intermediate sites, or at the final destination. The transported material then may vary from whole trees or slash to tree sections or chips. The solid contents of these materials can differ by a factor of five (Table 6). Small trees and residues have inherent disadvantages compared to larger roundwood material.

Table $6 . \quad$ Solid content percentages for uncompacted materials.

$\begin{array}{ll}\text { Logging residues } & 15 \text { to } 20 \\ \text { Trees/tree sections } & 35 \text { to } 40 \\ \text { Chips } & 40 \\ \text { Pulpwood } & 60 \text { to } 70\end{array}$

If processed into short length roundwood form, small trees can be loaded onto conventional pulpwood trucks. Self-loading trucks are necessary where the amount or flow rate cannot justify a separate loader. Payloads have been increased by using demountable cranes which are left at the landing.

Transportation of undelimbed tree sections has been more successful than hauling whole trees because the taper effect is eliminated. Conventional trucks may be modified to haul tree sections by adding full sides to the bunks. The sides slightly reduce net payload. Loading of tree sections is slower than for roundwood, but legal load weights can be achieved when operators become familiar with the material (Bjorheden, 1986). Low density materials such as logging residues can be transported in special high volume vehicles or by using compaction devices, or via a combination of the two. Either of these methods increases the tare weight of the vehicle. Vehicles in use in Sweden have approximately 10\% less net weight capacity than conventional roundwood trucks.

Legal-limit payloads of fuel chips can be achieved with conventional chip trucks. Container trucks with changeable containers are used effectively where small amounts of material are processed. The higher costs of extra containers and smaller payloads limits the container systems to shorter haul distances. 
Because of the finite loading and unloading times, transport costs increase less than proportionately with distance. Because of lower payload weights, hauling costs for unprocessed small trees' and residues are more sensitive to haul distance than are the costs for roundwood or chips.

Future Trends. Truck configurations will probably be similar to those of today. Standard roundwood vehicles may evolve into more flexible designs so that simple modifications will allow haulage of chips or fuel raw materials. The sixes of changeable containers may increase, as may the volumes of chip trucks and bulk cargo vehicles. More self-loading trucks with demountable loaders will be employed. Changes in regulations will have major impacts. When the maximum gross weight in Sweden is raised from the current 56 tonnes to 60 tonnes in 1995, the economic supply area for fuel is expected to double.

\section{DISCUSSION AND SUMMARY}

Most of the use of forest biomass for energy is by the forest industry, utilizing residues taken to mills with conventional products instead of the recovery of forest residues. Harvesting technologies are improving and costs to recover forest biomass for fuel are decreasing. Major increases in the use of forest biomass will not occur until (a) oil prices rise, or (b) political decisions are made to increase utilization.

Political decisions rather than current economics account for most of the current use of small trees and forest residues for energy other than home heating. This is true in Denmark, Sweden and parts of the United States. Based on present market prices for alternative sources of energy, the use of small trees and forest residues is not economically justifiable in most cases. Many countries are continuing to experiment with technology for collecting and processing this material, based on expected future increases in prices of fossil fuels.

\section{Residues}

Residues from processing are located on cutover areas, at roadside, and at central processing yards. In many parts of the world, the current management policy is to leave a higher percentage on site to recycle nutrients, reduce site disturbance, and eliminate accumulations of residues at roadside.

Table 7. Commonly used harvesting systems for residues and small trees

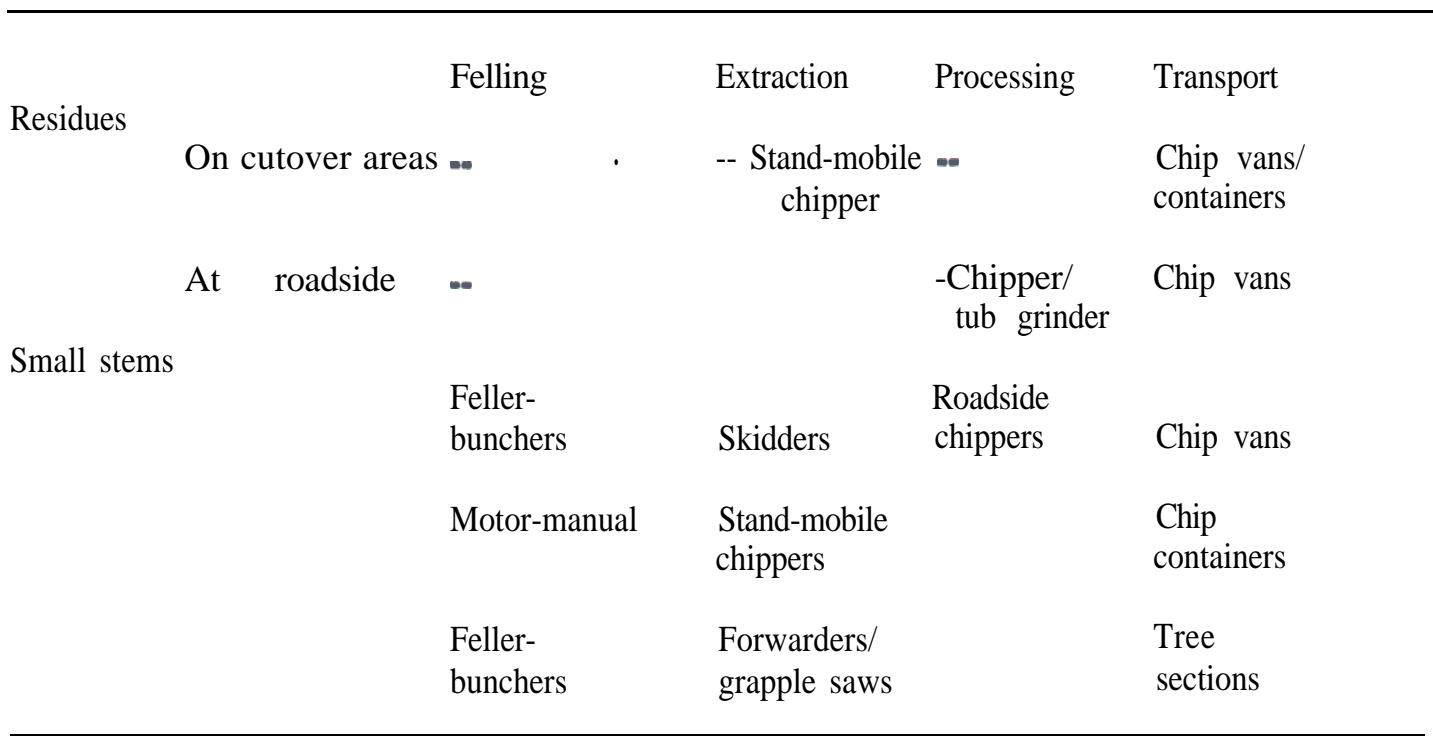


The most commonly employed systems for harvesting small stems and residues are shown in Table 7. . Residue collection from cutover areas is usually the most expensive option because the material is widely spread, small in size, non-uniform in shape, and difficult to compact. At present, stand mobile chippers are the most commonly used equipment for processing these residues.

Materials accumulated at roadside are cheaper to utilize than residues on cutover sites. Bulk densities must be increased to make transport economically feasible, so most materials are comminuted before transport. Drum chippers and tub grinders are used with roadside residues for size reduction.

\section{Small Trees}

Sources of small trees include thinnings, preharvests and postharvests of sites logged for other products, and conversion of low-value stands. Preharvesting generally recovers more material than postharvesting, usually at lower costs. Trees are less costly to handle and have higher bulk densities than forest residues. Most countries, therefore, utilize small trees to a greater extent than residues.

The most common harvesting system employs mechanical felling and bunching, skidding of whole trees, and chipping at roadside. This is usually the least expensive system in clearfelling and on large tracts. For smaller harvest volumes such as thinnings and on small tracts such as occur in Denmark and the United Kingdom, stand-mobile chippers are less expensive and more widely used.

In Sweden, where pulp chip values are higher than fuel values, tree-section methods allow the recovery of pulp and fuel products for separation by drum delimber/debarkers. The method could be used to produce fuel alone. Tree-section transport has been improved and is competitive with chip transport. Higher load volumes can be obtained with tree sections and with whole trees. In the United States, chain flail delimber/debarkers separate the two products at roadside. Clean boles are chipped and the residues are comminuted by tub grinders on a limited basis to increase the bulk density for transport.

\section{Emerging_Technologies/FutureTrends}

Especially in the United States and Canada, chain flail delimbing/debarking is gaining popularity for producing clean chips for pulp at roadside. The residues from flails differ from most common material produced by stroke or roll processors, or from motor-manual processing. They are smaller and are more concentrated, and in many cases exit the processing unit on a conveyor. This makes recovery easier. Tub grinders are being tested and improved for comminution of these residues to increase the bulk density before transport.

Although chip harvesters have not been successfully developed beyond the prototype stage, interest in such machines continues. A French machine is being tested in Canada for harvesting small stems.

Transport costs contribute significantly to the total costs of biomass fuels. Larger load capacities have major impacts on transportation economics. Changes in regulations in Sweden will increase the maximum gross vehicle weight by seven percent; this is expected to double the economic supply area for fuel. Vehicles with larger payloads, such as B- trains, are increasing in popularity in North America, both for shortwood and chips. Roundwood trucks with more flexible designs may be developed so that quick conversions will allow transport of fuel raw material or chips on the same vehicle.

\section{Activity Benefits}

The key benefit has been communications, collaboration, and transfer of information. Those contributing included the country representatives, industry personnel, and other participates in the 1989 International Symposium, 1990 Workshop, and annual study tours. Publication of the proceedings of the meetings, special reports, and four databases allowed the dissemination of technical information to a 
much wider audience. While it is impossible to quantify the benefits, the information exchange has probably improved the processing and handling of forest biomass for $\mathrm{e}_{\mathrm{n}}$ ergy, or, at least, provided the impetus for further research, evaluation, and development.

\section{REFERENCES}

Axelsson, J. and R. Bjorheden (1991). Truck systems for transportation of small trees and forest residues Final report. International Energy Agency - Bioenergy Agreement, Task VI, Activity 3, U.S. Department of Agriculture, Forest Service, Southern Forest Experiment Station, Auburn, AL. 32 p.

Baldini, S. and R. Spinelli (1990). Harvesting small stems from maritiime pine first thinnings. In: Harvesting Small Trees and Forest Residues Workshop (B.J. Stokes, ed.), Proceedings from IEA, Task VI, Activity 3 Workshop; 1990 May 28, Copenhagen, Denmark, Auburn, AL: U.S. Department of Agriculture, Forest Service, Southern Forest Experiment Station. pp. 74-83.

Baughman, R.K., B.J. Stokes and W.F. Watson (1990). Utilizing residues from in-woods flail processing. In: Harvesting Small Trees and Forest Residues Workshop (B.J. Stokes, ed.), Proceedings from IEA, Task VI, Activity 3 Workshop; 1990 May 28, Copenhagen, Denmark, Auburn, AL: U.S. Department of Agriculture, Forest Service, Southern Forest Experiment Station. pp. 2 1-30.

Bjorheden, R. (1986). Wood fuels in Jamtland - an evaluation of accessibleproduction systems for forest fuels in the Swedish county of Jamtland. Swedish University of Agricultural Sciences, Dept. of Operational Efficiency, Results No. 68.

Brinker, R.W. and R.A. Tufts (1989). Whole-tree chpping in the Southern United States. In: Harvesting Small Trees and Forest Residues (B.J. Stokes, ed.), Proceeding:s from an International Symposium; June 5-7, Auburn, AL, Auburn, AL: U.S. Department of Agriculture, Forest Service, Southern Forest Experiment Station. pp. 140-149.

Bnmberg, B. and G. Svenson (1990). Multi-tree handling can reduce first-thinning costs. In: Harvesting Small Trees and Forest Residues Workshop B.J. Stokes, ed.), Proceedings from IEA, Task VI, Activity 3 Workshop; 1990 May 28, Copenhagen, Denmark Auburn, AL: U.S. Department of Agriculture, Forest Service, South\& Forest Experiment Station. pp. 8-20.

Edman, F.T. (1989). Small stem thinning in the Pacific Northwest with barking and chipping in the woods. In: Harvesting Small Trees and Forest Residues (B.J. St $\alpha e s$, ed.), Proceedings from an International Symposium; June 5-7, Auburn, AL, Auburn, AL: US. Department of Agriculture, Forest Service, Southern Forest Experiment Station. pp. 126-130.

FERIC (1990). A databank oftransportation equipmentfor smalltrees and forest residues. Final Report - The Forest Engineering Institute of Canada.International Energy Agency - Bioenergy Agreement, Task VI, Activity 3, U.S. Department ofAgriculture, Forest Service, Southern Forest Experiment Station, Auburn, AL. 47 p.

Froding, A. (1989). The development of pulp chip harvesters for smal trees. In: Harvesting Small Trees and Forest Residues (B.J.Stokes, ed.), Proceedings from an Inernatio nal Symposium; June 5-7, Auburn, AL, Auburn, AL: U.S. Department of Agriculture, Fores Serv ice, Southern Forest Experiment Station. pp. 57-74.

Gingras, J.-F. (1989). Harvesting small trees - the Eastern Canadianstory. In: Harvesting Small Trees and Forest Residues (B.J. Stokes, ed.), Proceedings from an[ifternation; al Symposium; June 5-7, Auburn, AL, Auburn, AL: U.S. Department of Agriculture, Fores Servi ce, Southern Forest Experiment Station. pp. 118-125.

Gingras, J.-F. (1990). Harvesting small trees and forest residuals inCanada: 1990 update. In:

Harvesting Small Trees and Forest Residues Workshop (B.JStokes, e d.), Proceedings from IEA, Task VI, Activity 3 Workshop; 1990 May 28, Copenhagen,Denmark, Auburn, AL: U.S. Department of Agriculture, Forest Service, Suthern Forest Experiment Station. pp. 50-56.

Gjolsjo, S. (1988). Comparative studies on storage Production, Storage and Utilization of Wod Fuels (O. Gislerud, ed.), Proceedings of IEA/BA, Task III, Activity 6 \& 7, Symposium, Uppsla, Sweden.

Guimier, D.Y. (1989). Harvesting forest biomass for fuel: the EasternCanadian experience. In: Harvesting Small Trees and Forest Residues (B.J. Stokes, ed.)Proceeding gs from an International 
Symposium; June 5-7, Auburn, AL, Auburn, AL: U.S. Department of Agriculture, Forest Service, Southern Forest Experiment Station. pp. 1-10.

Hankala, T. (1988). Possibilities to increase the use of wood fuel by regions in Finland. In: Economic Evaluations of Biomass Oriented Systemsfor Fuel (G. Lonner and A. Tomquist, eds.), Proceedings of IEA/BA, Task III, Activity 4, Symposium, Garpenburg, Sweden.

Hartsough, B.R. (1989). Harvesting small stems and forest residues in the Pacific Southwestern United States. In: Harvesting Small Trees and Forest Residues (B.J. Stokes, ed.), Proceedings from an International Symposium; June 5-7, Auburn, AL, Auburn, AL: U.S. Department of Agriculture, Forest Service, Southern Forest Experiment Station. pp. 100-107.

Hartsough, B.R. and B.J. Stokes. (1990a). Comparison and feasibility of North American methods for harvesting small trees and residues for energy. In: Harvesting Small Trees and Forest Residues Workshop (B.J. Stokes, ed.), Proceedings from IEA, Task VI, Activity 3 Workshop* 1990 May 28, Copenhagen, Denmark, Auburn, AL: U.S. Department of Agriculture, Forest S\&vice, Southern Forest Experiment Station. pp. 3 1-40.

Hartsough, B.R. and B.J. Stokes. (1990b). A database of non integrated North American methods for harvesting small trees and residues for energy. Final Report. International Energy Agency. Bioenergy Agreement, Task VI, Activity 3, U.S. Department of Agriculture, Forest Service, Southern Forest Experiment Station, Auburn, AL. 22 p.

Hultkrantz, L. (1988). The consequences for the forest sector of nuclear power discontinuation in Sweden. In: Economic Evaluations of Biomass Oriented Systems for Fuel (G. Lonner and A. Tomquist, eds.), Proceedings of IEA/BA, Task III, Activity 4, Symposium, Garpenburg, Sweden. Johnson, L.R. (1989). Recovery of wood residues in the Intermountain region. In: Harvesting Small Trees and Forest Residues (B.J. Stokes, ed.), Proceedings from an International Symposium; June 5-7, Auburn, AL, Auburn, AL: U.S. Department of Agriculture, Forest Service, Southern Forest Experiment Station. pp. 11-3 1.

Kofman, P.D. (1990). Multiple-tree handling in Denmark In: Harvesting Small Trees and Forest Residues Workshop (B.J. Stokes, ed.), Proceedings from IEA, Task VI, Activity 3 Workshop; 1990 May 28, Copenhagen, Denmark, Auburn, AL: U.S. Department of Agriculture, Forest Service, Southern Forest Experiment Station. pp. 1-7.

Kvist, G. (1988). Integrated systems for harvest and utilization of wood fuels at SCA Skog AB. In: Economic Evaluations of Biomass Oriented Systems for Fuel (G. Lonner and A. Tomquist, eds.), Proceedings of IEA/BA, Task III, Activity 4, Symposium, Gatpenburg, Sweden.

Lambert, M.B. (1989). Harvesting small stems and forest residues in the Pacific Northwestern United States. In: Harvesting Small Trees and Forest Residues (B.J. Stokes, ed.), Proceedings from an International Symposium; June 5-7, Auburn, AL, Auburn, AL: U.S. Department of Agriculture, Forest Service, Southern Forest Experiment Station. pp. 90-99.

Lisland, T. (1990). Harvesting small trees and forest residues in Norway. In: Harvesting Small Trees and Forest Residues Workshop (B.J. Stokes, ed.), Proceedings from IEA, Task VI, Activity 3 Workshop; 1990 May 28, Copenhagen, Denmark Auburn, AL: U.S. Department of Agriculture, Forest Service, Southern Forest Experiment Station. pp. 4147.

Manning, G.H. (1987). Biomass for energy in British Columbia: good news or bad news. In: Harvesting Whole Trees with Processing in the Forest to Conventional and Energy Products (A.A. Twaddle, ed.), Proceedings of IEA/BA, Task 3, Project Al, Vol. 1, Vancouver, BC Canada.

McConchie, M. and C.J. Terlesk (1990). Accumulation of thinnings for extraction in New Zealand. In: Harvesting Small Trees and Forest Residues Workshop (B.J. Stokes, ed.), Proceedings from IEA, Task VI, Activity 3 Workshop; 1990 May 28, Copenhagen, Denmark, Auburn, AL: U.S. Department of Agriculture, Forest Service, Southern Forest Experiment Station. pp. 57-73.

McKnight, P.B. (1988). Wood biomass fuels on Prince Edward Island. In: Economic Evaluations of Biomass Oriented Systems for Fuel (G. Lonner and A. Tomquist, eds.), Proceedings of IEA/BA, Task III, Activity 4, Symposium, Gatpenburg, Sweden.

McMinn, J.W. and A. Clark III (1989). In: Harvesting Small Trees and Forest Residues (B.J. Stokes, ed.), Proceedings from an International Symposium; June 5-7, Auburn, AL, Auburn, AL: U.S. Department of Agriculture, Forest Service, Southern Forest Experiment Station. pp. 184-189. Mikkonen, E. (1989). Recent developments in small tree harvesting in Finland. In: Harvesting Small Trees and Forest Residues (B.J. Stokes, ed.), Proceedings from an International Symposium; 
June 5-7, Auburn, AL, Auburn, AL: U.S. Department of Agriculture, Forest Service, Southern Forest Experiment Station. pp. 44-50.

Mitchell, C.P., J.B. Hudson, D.N.A. Gardner and P.G. Storry (1989). Systems for harvesting wood for energy in the UK. In: Harvesting Small Trees and Forest Residues (B.J. Stokes, ed.), Proceedings from an International Symposium; June 5-7, Auburn, AL, Auburn, AL: U.S. Department of Agriculture, Forest Service, Southern Forest Experiment Station. pp. 51-56.

Molbak, I. and P. Kofman (199 1). Scandinavian chipping techniques - computer database. Final Report. International Energy Agency - Bioenergy Agreement, Ta,sk VI, Activity 3, U.S. Department of Agriculture, Forest Service, Southern Forest Experiment Station, Auburn, AL.

Petajisto, L. (1988). Heatingplants - assessment of profitable harvestable wood quantities. Skog, K. 1989. Current and projected wood energy consumption in the United States. Biologue, April/May pp. 16-17.

Pollini, C., G. Leonelli and G. Gios (1989). A new model of work cycle in the alpine logging operations. In: Harvesting Small Trees and Forest Residues (B.J. Stokes, ed.), Proceedings from an International Symposium; June 5-7, Auburn, AL, Auburn, AL: U.S. Department of Agriculture, Forest Service, Southern Forest Experiment Station. pp. 150-161.

Pottie, M.A. (1987). Harvesting whole trees with processing in the forest to conventional and energy products - favored systems and equipment for Canada. In: Harvesting Whole Trees with

Processing in the Forest to Conventional and Energy Products (A.A. Twaddle, ed.), Proceedings of IEA/BA, Task 3, Project Al, Vol. 2, Vancouver, BC Canada.

Raymond, K. (1989). Mechanized smallwood thinning in New Zealand. In: Harvesting Small Trees and Forest Residues (B.J. Stokes, ed.), Proceedings from an International Symposium; June 5-7, Auburn, AL, Auburn, AL: U.S. Department of Agriculture, Forest Service, Southern Forest Experiment Station. pp. 75-83.

Steinmann, P.A. (1990). Wood fuel usage and harvesting in Switzerland. In: Harvesting Small Trees and Forest Residues Workshop (B.J. Stokes, ed.), Proceedings from IEA, Task VI, Activity 3 Workshop; 1990 May 28, Copenhagen, Denmark, Auburn, AL: U..S. Department of Agriculture Forest Service, Southern Forest Experiment Station. pp. 4849.

Stephenson, E.H. (1989). Flail debarking: a historical pe rspective and review of current technology. In: Harvesting Small Trees and Forest Residues (B.J. Stokes, ed.), Proceedings from an International Symposium; June 5-7, Auburn, AL; Auburn, AL: U.S. Department of Agriculture, Forest Service, Southern Forest Experiment Station. pp. 162-169.

Stokes, B.J. and D.L. Sirois (1989). Recovery of forestt residues in the Southern United States. In:

Harvesting Small Trees and Forest Residues (B.J. Stokes, ed.), Proceedings from an International Symposium; June 5-7, Auburn, AL, Auburn, AL: U.S. Department of Agriculture, Forest Service, Southern Forest Experiment Station. pp. 32-43.

Sturos, J.A. and M.A. Thompson (1989). Harvesting small stems and forest residues in the Lake States. In: Harvesting Small Trees and Forest Residues (B.J. Stokes, ed.), Proceedings from an International Symposium; June 5-7, Auburn, AL, Auburn, AL: U.S. Department of Agriculture, Forest Service, Southern Forest Experiment Station. pp. 108-1 17.

Suadicani, K. (1989). Harvesting small trees in Denmark. In: Harvestinig Small Trees and Forest

Residues (B.J. Stokes, ed.). Proceedings from an International Symposiurn; June 5-7, Auburn, AL, Auburn, AL: U.S. Department of Agriculture, Forest Service, Southem Forest Experiment Station. pp. 84-89.

Twaddle, A.A. (1987). Review of systems for whole tree harvesting: New Zealand. In: Harvesting Whole Trees with Processing in the Forest to Conventional and Energy Products (A.A. Twaddle, ed.), Proceedings of IEA/BA, Task 3, Project Al, Vol. 2, Vancouver, BC Canada.

Twaddle, A.A., B.J. Stokes and W.F. Watson (1989). Harvestingsmal't stems and residues for biofuels: an internationalperspective. ASAE Paper No. 89-7545. American Society of Agricultural Engineers, St. Joseph, MI. 16 p.

Watson, W.F. and B.J. Stokes (1989). Harvesting small stems - a Southern USA perspective. In: Harvesting Small Trees and Forest Residues (B.J. Stokes, ed.), Proceedings from an International Symposium; June 5-7, Auburn, AL, Auburn, AL: U.S. Department of Agriculture, Forest Service, Southern Forest Experiment Station. pp. 131-139.

Young, T.M., D.M. Ostermeier, R.W. Mulach, J.D. Thomas and R.T. Brooks, Jr. (1989). A simulation of harvesting systems for economic supply models. In: Harvesting Small Trees and Forest 
Residues (B.J. Stokes, ed.), Proceedings from an International Symposi ; June 5-7, Auburn, AL, Auburn, AL: U.S. Department of Agriculture, Forest Service, Southe Forest Experiment Station. pp. 170-183. 